\title{
THE EFFECT OF BACTERIAL APPLICATION ON THE PRODUCTIVITY OF FABA BEAN (VICIA FABA L.) AND ITS MIXTURE WITH SPRING WHEAT (TRITICUM AESTIVUM L.) UNDER TWO AGROCLIMATIC CONDITIONS IN LITHUANIA
}

\author{
ŠIAUDINIS, G..$^{1 *}$ - ARLAUSKIENE், A. ${ }^{2}$ - REPŠIENĖ, R. ${ }^{1}$ - ŠARŪNAITE், L. ${ }^{3}$ - \\ SKUODIENĖ, R. ${ }^{1}$ \\ ${ }^{1}$ Véžaičiai Branch of the Lithuanian Research Centre for Agriculture and Forestry \\ Gargždu 29, Véžaičiai, Lithuania \\ ${ }^{2}$ Joniškèlis Branch of the Lithuanian Research Centre for Agriculture and Forestry \\ Joniškèlis LT-39301, Pasvalys distr., Lithuania \\ ${ }^{3}$ Institute of Agriculture, Lithuanian Research Centre for Agriculture and Forestry \\ Instituto 1, LT-58344, Kédainiai distr., Lithuania \\ *Corresponding author \\ e-mail: gintaras.siaudinis@vezaiciai.lzi.lt; phone: +370-46-45-82-33
}

(Received $12^{\text {th }}$ Jul 2017; accepted $27^{\text {th }}$ Oct 2017)

\begin{abstract}
Recently there has been a renewed interest in the optimization and development of legume cultivation technologies in many European Countries. By choosing the species which fit well the local soil and weather conditions might be an excellent solution to obtain a high fodder and grain yield. Field trials with faba bean (Vicia faba L.) and faba bean spring wheat (Triticum aestivum L.) mixture were conducted to evaluate the effect of seed inoculation with Rhizobium strain on the productivity of faba bean and its mixture with spring wheat. The study was conducted at two sites, Joniškèlis Experimental Station (site I) and Vèžaičiai Branch (site II) of the Lithuanian Research Centre for Agriculture and Forestry. The findings obtained in site I revealed that the dry matter (DM) yield of crops at the pod development stage averaged $7575 \mathrm{~kg} \mathrm{ha}^{-1}$ and the grain yield averaged $6067 \mathrm{~kg} \mathrm{ha}^{-1}$; the corresponding values for site II were $5684 \mathrm{~kg} \mathrm{ha}^{-1}$ and $4937 \mathrm{~kg} \mathrm{ha}^{-1}$, respectively. In most cases, the content of nutrients crude proteins, crude fat, crude fibre, neutral detergent fibre, and crude ash in the biomass was higher in site I. The faba bean - spring wheat mixture produced a higher grain yield and a higher metabolizable energy content in grains compared with the faba bean grown as a sole crop; other measured parameters did not reveal the superiority of the mixture over the sole faba bean. Rhizobium spp. application had a positive impact by increasing the above-ground biomass DM yield and grain yield in a sole crop as well as in a mixture with wheat.
\end{abstract}

Keywords: legume, mixture, dry matter production, seed quality, grain yield, Rhizobium spp.

\section{Introduction}

Due to the increasing production area of cereals and oil crops in many European Countries, as well as the introduction of modern plant protection means, the area under legume crops and their role in crop rotation systems significantly decreased (Pascual and Perrings, 2007). According to the statistics, the area under legumes in the EU countries has declined from 5.8 million ha (in 1960) to 1.7 million ha (in 2013). Soybean (Glycine max (L.) Merr.) is a dominant legume crop, representing $50 \%$ of the global legume crop area and 68\% of global production (Herridge et al., 2008). Meanwhile in Europe, common pea (Pisum sativum L.) and faba bean (Vicia faba L.) are the predominant legumes. However, in order to diminish the dependence on import material (particularly soya bean meal) from America Continent and increase 
biodiversity according to the "greening" programme, some legume species have good prospects in the coming decades. Accordingly, the legume species have a huge potential worldwide (Jensen et al., 2015). Legume cultivation and economic profit depend on numerous factors, including economic, political, climatic, and social ones in each region and country (Pilorge and Muel, 2016). Grain-legumes have many functional and nutritional properties both as feed and food (Voisin et al., 2014; Magrini et al., 2016).

Recently in Lithuania, as well as in other countries of temperate climate, the area under faba bean has been steadily increasing (Siddique et al., 2012). Despite the fact that faba bean is more sensitive to biotic and abiotic factors than other legumes, it has a higher capacity for $\mathrm{N}$ fixation, higher photosynthetic activity, thus forming higher above-ground biomass (Jensen et al., 2010). In Lithuania, faba bean is an important protein source for both food and feed (Jensen et al., 2010). To improve feed quality, legumes are often grown in a mixture with barley, oats and other cereals (Strydhorst et al., 2008). Such mixtures could sustain more stable yields, improve nutrient cycling in the soil, perform better in terms of resource use efficiency, provide better protection against weeds, diseases and pests, and increase biodiversity (McKenzie, 1999; Strydhorst et al., 2008; Šarūnaitè et al., 2013).

Legumes are not only a source of protein, they also play a significant role in the nitrogen cycle in the biosphere due to their most important ecological process - atmospheric nitrogen fixation (Bloemberg and Lugtenberg, 2001). The cultivation of faba bean and other legumes has an important economic benefit in sustainable cropping systems, which allows reduction of of mineral $\mathrm{N}$ fertilizer use, whose manufacturing requires fossil materials (Nemecek et al., 2008; Bedoussac et al., 2015). Each year, in agricultural systems, annual crops capture up to 50-70 Tg of atmospheric nitrogen (Herridge et al., 2008). The inoculation of faba bean seeds with Rhizobium strains has a positive effect on the symbiotic $\mathrm{N}$ fixation rate, aboveground biomass of crops as well as seed productivity (Lapinskas, 2006; Elkoca et al., 2007). Rhizobium bacterial activity is the most efficient in the soils that had been intensively managed, including heavy input of chemicals, for many years and no bacterial agents had been used for more than 10 years.

Inoculation of faba bean seeds is an efficient tool to increase crops productivity in a crop rotation and enhance economic profitability. Although the positive role of faba bean has been known for a long time, the growing technology needs to be refined and optimized. It has been well documented that inoculation of legume grains by bacterial strains is an efficient way of introducing effective Rhizobia to the soil and the rhizosphere of legumes. Threrefore, much work has still to be done in order to realize the full productivity potential of faba bean (Deaker et al., 2004).

The aim of the current study work was to get a better understanding and evaluate the efficiency of Rhizobium application on faba bean and faba bean - wheat mixture and their productivity in the two locations, differing in precipitation regime and soil type.

\section{Materials and methods}

Field experiments were carried out in two locations differing in the agroclimatic contitions: Joniškeelis Experimental Station (site I) and Véžaičiai Branch (site II) of the Lithuanian Research Centre for Agriculture and Forestry. Joniškèlis Experimental Station is situated in the northern part of Central Lithuania's lowland $\left(56^{\circ} 12^{\prime} \mathrm{N}, 24^{\circ} 20^{\prime}\right.$ E). The soil of this experimental site is Endocalcaric Endogleyic Cambisol (Siltic, Drainic) (clay $\left(<0.002 \mathrm{~mm}\right.$ ) - $27.0 \%$ ) with $\mathrm{pH}_{\mathrm{KCl}} 6.5-7.0, \mathrm{P}_{2} \mathrm{O}_{5}$ and $\mathrm{K}_{2} \mathrm{O}-198 \mathrm{mg} \mathrm{kg}^{-1}$ 
and $273 \mathrm{mg} \mathrm{kg}^{-1}$, respectively, humus - 2.8-3.0\%. The annual amount of precipitation is $500-600 \mathrm{~mm}$, and most precipitation falls in the spring - summer period. Véžaičiai branch is located in the seaside lowland eastern edge (Western Lithuania, 55 $43^{\prime} \mathrm{N}, 21^{\circ}$ $\left.27^{\prime} \mathrm{E}\right)$. The soil of this experimental site is naturally acid, moraine loamy Bathygleyic Dystric Glossic Retisol (WRB, 2014), (clay $(<0.002 \mathrm{~mm})-15.0 \%), \mathrm{pH}_{\mathrm{KCl}} 5.2-5.5, \mathrm{P}_{2} \mathrm{O}_{5}$ and $\mathrm{K}_{2} \mathrm{O}-200 \mathrm{mg} \mathrm{kg}^{-1}$ and humus $2.2-2.3 \%$. The annual amount of precipitation is $700-900 \mathrm{~mm}$ and most of it occurs in the autumn and early winter period.

\section{Experimental designs and details}

The experimental site was divided into two strips (factor - crops) - faba bean as sole crop and faba bean - spring wheat mixture. Further, each strip was randomly split into two smaller strips (factor - Rhizobium application) - without Rhizobium application and with Rhizobium application. The plots were sowin at the rates of 0.65 million ha ${ }^{-1}$ (65 faba bean plants $\mathrm{m}^{-2}$ ) of viable faba bean seeds (in sole crop) and 0.40 million $^{-1}$ of viable faba bean seeds +2.5 mlillion ha $^{-1}$ viable spring wheat seeds ( 40 faba bean plants $\mathrm{m}^{-2}$ and 250 wheat plants $\mathrm{m}^{-2}$ ). Faba bean seeds (cv. Bioro) were inoculated with microbial fertilizer Rhizobium leguminosarum $b v$. fabae just before the sowing. The rate of phosphorus (single superhosphate) was equal for all treatment $-60 \mathrm{~kg} \mathrm{ha}^{-1} \mathrm{P}_{2} \mathrm{O}_{5}$. other fertilizers have not been used. Fertilizers were incorporated into the soil with a combined seed drill together with seeds.

\section{Plant analyses}

The dry matter yield was assessed at a pod development stage on July 18 and July 16 in site I and site II, respectively and at a full maturity stage (grain yield adjusted to $14 \%$ moisture) on August 20 and August 11 in site I and site II respectively.

The following chemical parameters were analysed: crude proteins (CP) (after Kjeldahl ), crude fat (CF) (Soxhlet extraction method), water-soluble carbohydrates (WSC), crude fibre (Cfib) (by Henneberg and Stohman method), neutral detergent fibre (NDF) (by Van Soest method) and crude ash (CA) (gravimetrically). All analyses were done at the Chemical Laboratory of the Lithuanian Research Centre for Agriculture and Forestry.

The data of all studied parameters and their interactions were statistically processed using analysis of variance (ANOVA) as a three factorial randomized block variant to determine significant differences between means ( $* \mathrm{P}<0.05$ and $* * \mathrm{P}<0.01), L S D_{05}$ and $L S D_{01}$ (at $95 \%$ and $99 \%$ probability levels) (Tarakanovas and Raudonius, 2003).

\section{Results and discussion}

According to the data of Fisher's criterion, at pod development stage, location/site (L) had an essential effect on all studied parameters: dry matter yield (DM kg ha ${ }^{-1}$ ), crude proteins $(\mathrm{CP})$, crude fat $(\mathrm{CF})$, crude fibre (CFib), crude ash (CA), water soluble carbohydrates (WSC), neutral detergent fibre (NDF) contents $\left(\mathrm{mg} \mathrm{kg}^{-1}\right.$ ) and energy value $\left(\mathrm{MJ} \mathrm{kg}^{-1}\right)(\mathrm{EV})($ at $\mathrm{p}<0.01)$ (Table 1). There were no significant differences in DM yield between the both crops (Cr) (growing faba bean as a sole crop and in mixture with spring wheat). However, there were significant differences (at $\mathrm{p}<0.01$ ) in all the studied chemical parameters as well as energy value beteween the both crops. Bacterial application ( $\mathrm{Rh}$ ) caused the differences between crops' DM yields (at $\mathrm{p}<0.05), \mathrm{CF}$, CFib, NDF contents as well as ME ( $p<0.01)$. There were significant differences 
between location and crop ( $\mathrm{LxCr}$ ) interaction in the following parameters: $\mathrm{CF}$, CFib, $\mathrm{CA}$ and ME (at $\mathrm{p}<0.01)$. The effect of location $(\mathrm{L})$ and bacterial $(\mathrm{Rh})$ interactions on the studied parameters (except insignificant effect on CA content) was similar. CrxRh interaction caused the differences in CF, Cfib (at $\mathrm{p}<0.01$ ) and CA (at $\mathrm{p}<0.05$ ) contents. With regard to the three factors' interaction between LxCrxRh, it gave a significant impact on $\mathrm{CP}, \mathrm{CF}$ and $\mathrm{CA}$ contents in the above-ground biomass (at $\mathrm{p}<0.01$ ).

Table 1. F statistics values for the studied parameters at pod development stage

\begin{tabular}{|l|c|c|c|c|c|c|c|c|}
\hline $\begin{array}{l}\text { Source of } \\
\text { variation }\end{array}$ & DM & CP & CF & WSC & CFib & NDF & CA & ME \\
\hline Loc. (L) & $46.94^{* *}$ & $1024.88^{* *}$ & $329.87^{* *}$ & $148.94^{* *}$ & $79.93^{* *}$ & $140.88^{* *}$ & $94.19^{* *}$ & $225.47^{* *}$ \\
\hline Crops $(\mathrm{Cr})$ & 1.61 & $46.81^{* *}$ & $101.51^{* *}$ & $33.78^{* *}$ & $31.84^{* *}$ & $83.6^{* *}$ & $15.12^{* *}$ & $91.76^{* *}$ \\
\hline Bact. $(\mathrm{Rh})$ & $6.15^{*}$ & 0.64 & $324.91^{* *}$ & 0.04 & $13.66^{* *}$ & $7.80^{* *}$ & 0.53 & $21.33^{* *}$ \\
\hline LxCr & 0.48 & 1.84 & $213.11^{* *}$ & 1.58 & $7.09^{*}$ & 0.93 & $7.90^{* *}$ & $40.78^{* *}$ \\
\hline LxRh & 2.08 & 0.96 & $221.19^{* *}$ & 0.07 & $23.50^{* *}$ & 0.44 & 0.12 & $24.35^{* *}$ \\
\hline CrxRh & 0.34 & 0.10 & $339.91^{* *}$ & 0.49 & $8.41^{* *}$ & 1.28 & $5.75^{*}$ & $31.48^{* *}$ \\
\hline LxCrxRh & 0 & $1024.88^{* *}$ & $514.65^{* *}$ & 0.69 & 0.23 & 3.22 & $9.51^{* *}$ & $34.71^{* *}$ \\
\hline
\end{tabular}

Note: DM - dry mater, CP - crude proteins, CF - crude fat, WSC - water soluble carbohydrates, CFib crude fibre, NDF - neutral detergent fibre, CA - crude ash.

At a full maturity stage, the location/site (L) as a factor had an essential effect on the grain yield (GY) and grain chemical parameters: $\mathrm{CP}, \mathrm{CF}, \mathrm{CFib}, \mathrm{CA}, \mathrm{WSC}$ and ME (at $\mathrm{p}<0.01)$ (Table 2). There was no difference between crops $(\mathrm{Cr}) \mathrm{SY}$; however, grain quality parameters as well as EV differed significantly (at $\mathrm{p}<0.01$ ). Bacterial application $(\mathrm{Rh})$ had an impact on $\mathrm{SY}(\mathrm{p}<0.05)$ and the following parameters: $\mathrm{CF}$, CFib, WSC, NDF and ME (at $p<0.01)$.

Table 2. F statistics values for the studied parameters in grain yield and seed quality parameters

\begin{tabular}{|c|c|c|c|c|c|c|c|c|}
\hline $\begin{array}{c}\text { Source of } \\
\text { variation }\end{array}$ & GY & CP & CF & WSC & CFib & NDF & CA & ME \\
\hline Loc. (L) & $29.12^{* *}$ & $46.29^{* *}$ & $6.12^{*}$ & $33.33^{* *}$ & $109.19^{* *}$ & 2.75 & $104.4^{* *}$ & 0.89 \\
\hline Crops (Cr) & 1.06 & $348.69^{* *}$ & $26.53^{* *}$ & $310.64^{* *}$ & $63.70^{* *}$ & $99.98^{* *}$ & $86.20^{* *}$ & $606.68^{* *}$ \\
\hline Bact. (Rh) & $7.39^{*}$ & 0.63 & $110.34^{* *}$ & $40.44^{* *}$ & $14.96^{* *}$ & $4.71^{*}$ & 2.72 & $61.08^{* *}$ \\
\hline LxCr & $8.72^{* *}$ & $244.4^{* *}$ & $4.62^{*}$ & $4.32^{*}$ & 0.31 & $20.73^{* *}$ & $6.85^{*}$ & 0.27 \\
\hline LxRh & 0.11 & 0.13 & 2.50 & $44.08^{* *}$ & $21.83^{* *}$ & 1.52 & $5.52^{*}$ & 1.17 \\
\hline CrxRh & 0.88 & 0.42 & 0 & 3.80 & $5.34^{*}$ & $5.48^{*}$ & 0.34 & $246.93^{* *}$ \\
\hline LxCrxRh & 0.11 & 2.31 & 0.59 & 1.86 & $12.07^{* *}$ & 0.80 & $29.35^{* *}$ & 1.64 \\
\hline
\end{tabular}

Note: DM - dry mater, CP - crude proteins, CF - crude fat, WSC - water soluble carbohydrates, CFib crude fibre, NDF - neutral detergent fibre, CA - crude ash.

Concerning the interactions among the different factors, $\mathrm{LxCr}$ was the most distinctive and strongest for the studied parameters: GY, CP, NDF and ME (at $\mathrm{p}<0.01$ ) as well as for $\mathrm{CF}, \mathrm{CA}$ and $\mathrm{ME}$ (at $\mathrm{p}<0.05$ ). The effect of the other two pairs of interaction was less noticeable. In this respect, $\mathrm{LxRh}$ interaction had a significant variation for CFib, WSC (at $\mathrm{p}<0.01$ ) and CA, ME (at $\mathrm{p}<0.05$ ); meanwhile CrxRh 
interaction significantly influenced CFib and NDF (at $\mathrm{p}<0.05$ ). The three-fold factorial interaction ( $\mathrm{LxCrxRh}$ ) had a significant impact for CFib and CA (at $\mathrm{p}<0.01$ ) only.

The data of the above-ground biomass dry matter (DM) yield at pod development stage are presented in Figures 1 and 2.

The results evidently showed that the location/site (growing under different soil and temperature regime) had an essential effect on DM yield. The average DM yield at site I (Joniškèlis) surpassed DM yield at site II (Vèžaičiai) by $33.27 \%$ (at $99 \%$ probability level). In both locations, when growing faba bean in mixture with spring wheat, DM yield was higher than that in sole crop; however, the increase of biomass was not statistically significant (at $95 \%$ level).

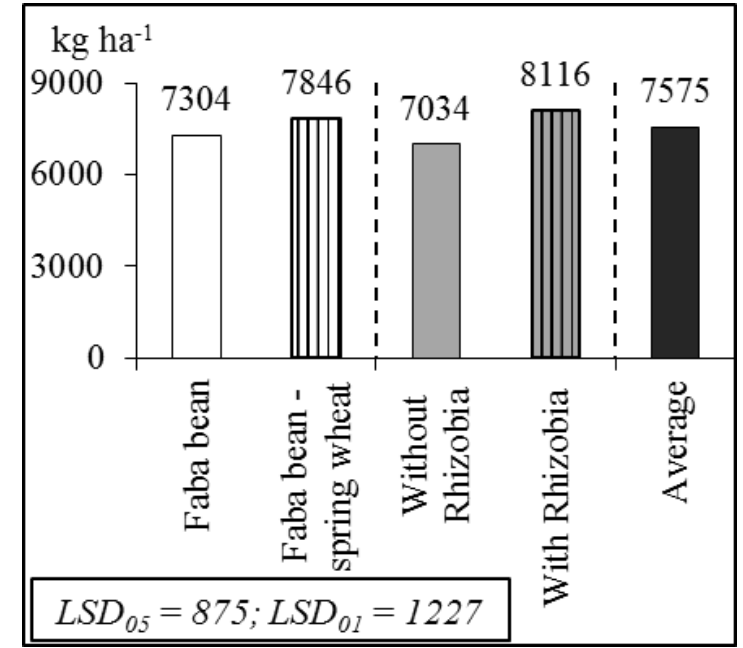

Figure 1. Faba bean and faba bean - spring wheat mixture $\left(\mathrm{kg} \mathrm{ha}^{-1}\right)$ dry matter (DM) at pod development stage as affected by crop and Rhizobium application at site I

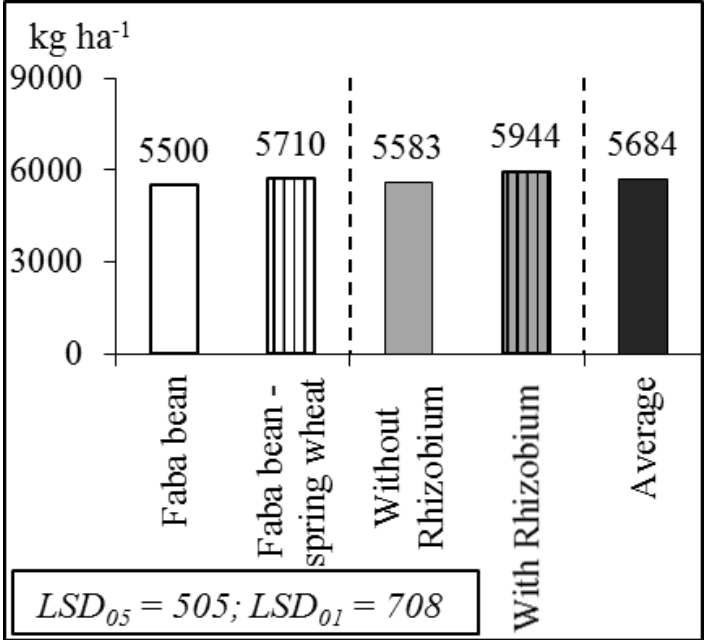

Figure 2. Faba bean and faba bean - spring wheat mixture $\left(\mathrm{kg} \mathrm{ha}^{-1}\right)$ dry matter $(\mathrm{DM})$ at pod development stage as affected by crop and Rhizobium application at site II

The inoculation of seeds with of Rhizobium had a significant and positive effect on biomass productivity. DM yield increased from $7034 \mathrm{~kg} \mathrm{ha}^{-1}$ to $8116 \mathrm{~kg} \mathrm{ha}^{-1}$ (by 15.38 $\%$ ) (in site I) and from $5583 \mathrm{~kg} \mathrm{ha}^{-1}$ to $5944 \mathrm{~kg} \mathrm{ha}^{-1}$ (in site II) (both at $95 \%$ probability level).

The highest grain productivity was obtained at site I where the yield averaged 6067 $\mathrm{kg} \mathrm{ha}^{-1}$ and was by $22.89 \%$ higher than in site II) (Figs. 3 and 4).

The grain yield in the faba bean - spring wheat mixture amounted to $6268 \mathrm{~kg} \mathrm{ha}^{-1}$, which was by $6.87 \%$ higher than of sole bean crop (site I) (at $99 \%$ probability level). However, the opposite situation was observed at site II, where sole crop produced higher yield averaging $5353 \mathrm{~kg} \mathrm{ha}^{-1}$. As mentioned before, the sowing rate of faba bean to be grown in a mixture with cereals was lower compared to that of a sole crop. Further, the spring wheat plants were shorter than faba beans ("Bioro") (biometrical data are not presented), therefore beans shaded them, which resulted in a relatively smaller share of wheat plants in the mixture.

The application of Rhizobium resulted in a grain yield increase from $5817 \mathrm{~kg} \mathrm{ha}^{-1}$ (without inoculation) to $6316 \mathrm{~kg} \mathrm{ha}^{-1}$ (by $8.58 \%$ ) at site I and from $4617 \mathrm{~kg} \mathrm{ha}^{-1}$ to 5257 $\mathrm{kg} \mathrm{ha}^{-1}$ (by $13.86 \%$ ) at site II (both at $99 \%$ probability level). 


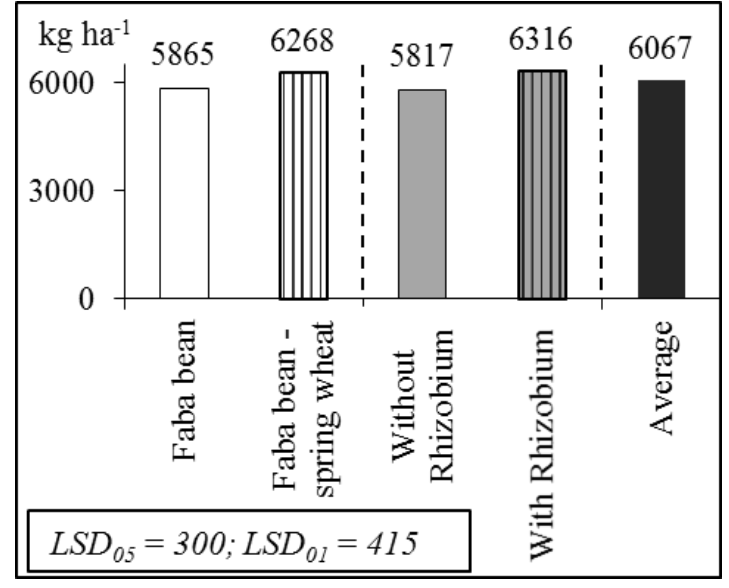

Figure 3. Faba bean and faba bean - spring wheat mixture $\left(\mathrm{kg} \mathrm{ha}^{-1}\right)$ grain yield $(14 \%$ moisture) at full maturity stage as affected by crop and Rhizobia application at site I

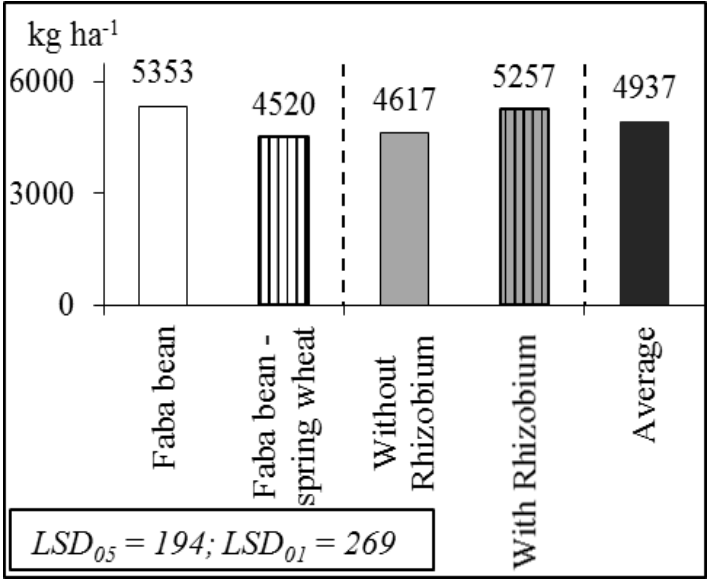

Figure 4. Faba bean and faba bean - spring wheat mixture $\left(\mathrm{kg} \mathrm{ha}^{-1}\right)$ grain yield $(14 \%$ moisture) at full maturity stage as affected by crop and Rhizobia application at site II

The data of chemical parameters of faba bean and faba bean - spring wheat biomass at faba bean pod developing stage are presented in Table 3.

Table 3. The contents of nutritional parameters in the above-ground biomass $(\mathrm{CP}, \mathrm{CF}$, WSC, CFib, NDF, CA $\left(\mathrm{g} \mathrm{kg}^{-1}\right)$ and metabolizable energy $\left(\mathrm{MJ} \mathrm{kg}^{-1}\right)$ content at pod development stage

\begin{tabular}{|c|c|c|c|c|c|c|c|}
\hline Variables & CP & CF & WSC & CFib & NDF & CA & ME \\
\hline \multicolumn{8}{|c|}{ Site I } \\
\hline Faba bean & 184 & 24.25 & 101.2 & 426 & 483 & 82.67 & 19.58 \\
\hline $\begin{array}{l}\text { Faba bean + } \\
\text { spring wheat }\end{array}$ & 172 & 28.75 & 81.17 & 414 & 524 & 80.83 & 19.51 \\
\hline $\begin{array}{c}\text { Without } \\
\text { Rhizobium }\end{array}$ & 180 & 29.50 & 91.83 & 438 & 509 & 80.83 & 19.59 \\
\hline $\begin{array}{c}\text { With } \\
\text { Rhizobium }\end{array}$ & 176 & 23.50 & 90.50 & 402 & 499 & 82.67 & 19.50 \\
\hline Average & 178 & 26.50 & 91.17 & 420 & 504 & 81.75 & 12.71 \\
\hline$L S D_{05 / 01}$ & $\begin{array}{l}3.43 / \\
4.81 \\
\end{array}$ & $\begin{array}{l}0.22 / \\
0.31 \\
\end{array}$ & $\begin{array}{l}6.47 / \\
9.07 \\
\end{array}$ & $\begin{array}{l}8.26 / \\
11.58 \\
\end{array}$ & $\begin{array}{l}10.08 / \\
14.13 \\
\end{array}$ & $\begin{array}{l}2.16 / \\
3.03 \\
\end{array}$ & $\begin{array}{l}0.020 / \\
0.028 \\
\end{array}$ \\
\hline \multicolumn{8}{|c|}{ Site II } \\
\hline Faba bean & 113 & 23.60 & 172 & 400 & 419 & 70.95 & 19.01 \\
\hline $\begin{array}{l}\text { Faba bean }+ \\
\text { spring wheat }\end{array}$ & 93.9 & 22.76 & 170 & 365 & 470 & 59.57 & 18.94 \\
\hline $\begin{array}{c}\text { Without } \\
\text { Rhizobium }\end{array}$ & 103 & 23.48 & 169 & 380 & 453 & 64.93 & 19.01 \\
\hline $\begin{array}{c}\text { With } \\
\text { Rhizobium }\end{array}$ & 104 & 22.90 & 174 & 385 & 436 & 65.58 & 19.01 \\
\hline Average & 104 & 23.19 & 171 & 383 & 444 & 65.26 & 12.68 \\
\hline$L S D_{05 / 01}$ & $\begin{array}{l}3.39 / \\
4.75 \\
\end{array}$ & $\begin{array}{l}0.24 / \\
0.34 \\
\end{array}$ & $\begin{array}{l}1.241 \\
1.74 \\
\end{array}$ & $\begin{array}{l}5.19 / \\
7.28 \\
\end{array}$ & $\begin{array}{c}4.87 / \\
6.82 \\
\end{array}$ & $\begin{array}{l}1.85 / \\
2.59 \\
\end{array}$ & $\begin{array}{l}0.017 / \\
0.024 \\
\end{array}$ \\
\hline
\end{tabular}

Note: CP - crude proteins, CF - crude fat, WSC - water soluble carbohydrates, CFib - crude fibre, $\mathrm{NDF}$ - neutral detergent fibre, CA - crude ash, ME - metabolizable energy. 
In most cases, (except for WSC), the average values of quality parameters, $(\mathrm{CP}, \mathrm{CF}$, CFib, NDF and CA) were higher at site I (Joniškèlis).

At site I, the contents of CP, WSC, CFib and CA in sole faba bean biomass were significantly higher than those in faba bean - spring wheat mixture by $6.98 \%, 24.68 \%$, $4.68 \%, 2.90 \%$ and $2.28 \%$, respectively; altogether, CF content in the biomass mixture was higher by $8.49 \%$. At site II, the higher contents of nutrient parameters were in sole faba bean biomass as well, where CP content was by $20.34 \%$, CF by $3.69 \%$, WSC by $1.18 \%$, CFib by $9.59 \%$, CA by $19.10 \%$ higher than in the faba bean - wheat mixture. Only the content of NDF was higher in the mixture by $10.85 \%$.

In many cases, the role of Rhizobium on the studied parameters was unambiguous; however, the application of bacterial application had no positive effect on the measured quality parameters.

As regards the amount of metabolizable energy, there were no significant differences between either the two sites or Rhizobia application. However, the share of the energy was higher in the faba bean sole crop than in the faba bean - wheat mixture.

Faba bean and faba bean - spring wheat chemical parameters in grains at full maturity stage was somewhat different from that at pod development stage (Table 4).

Table 4. The contents of nutritional parameters in faba bean - spring wheat grains (CP, CF, WSC,

$\mathrm{CFib}, \mathrm{NDF}, \mathrm{CA}\left(\mathrm{g} \mathrm{kg}^{-1}\right)$ and metabolizable energy $\left(\mathrm{MJ} \mathrm{kg}^{-1}\right)$ content at full maturity stage

\begin{tabular}{|c|c|c|c|c|c|c|c|}
\hline Variables & $\mathbf{C P}$ & CF & WSC & CFib & NDF & $\mathbf{C A}$ & ME \\
\hline \multicolumn{8}{|c|}{ Site I } \\
\hline Faba bean & 271 & 15.75 & 65.50 & 102.33 & 150 & 38.17 & 13.21 \\
\hline $\begin{array}{c}\text { Faba bean } \\
+ \text { spring wheat }\end{array}$ & 264 & 13.50 & 55.33 & 88.50 & 140 & 34.83 & 12.21 \\
\hline $\begin{array}{l}\text { Without } \\
\text { Rhizobia }\end{array}$ & 269 & 13.25 & 64.67 & 94.67 & 148 & 37.50 & 12.89 \\
\hline $\begin{array}{r}\text { With } \\
\text { Rhizobia }\end{array}$ & 266 & 16.00 & 56.17 & 96.17 & 142 & 35.50 & 12.54 \\
\hline I location & 267 & 14.62 & 60.42 & 95.42 & 145 & 36.50 & 11.79 \\
\hline$L S D_{05 / 01}$ & $\begin{array}{c}2.16 / \\
3.02 \\
\end{array}$ & $\begin{array}{c}0.355 / \\
0.498 \\
\end{array}$ & $\begin{array}{c}0.74 / \\
1.03 \\
\end{array}$ & $\begin{array}{l}2.54 / \\
3.57\end{array}$ & $\begin{array}{c}3.64 / \\
5.10 \\
\end{array}$ & $\begin{array}{c}0.90 / \\
1.26 \\
\end{array}$ & $\begin{array}{c}0.067 / \\
0.095 \\
\end{array}$ \\
\hline \multicolumn{8}{|c|}{ Site II } \\
\hline Faba bean & 291 & 14.32 & 63.08 & 83.90 & 162 & 34.37 & 13.16 \\
\hline $\begin{array}{c}\text { Faba bean } \\
+ \text { spring wheat }\end{array}$ & 212 & 13.40 & 50.20 & 67.98 & 134 & 28.42 & 12.19 \\
\hline $\begin{array}{l}\text { Without } \\
\text { Rhizobia }\end{array}$ & 252 & 12.00 & 56.55 & 83.90 & 149 & 31.22 & 12.81 \\
\hline $\begin{array}{r}\text { With } \\
\text { Rhizobia }\end{array}$ & 251 & 15.72 & 56.73 & 67.98 & 148 & 31.57 & 12.54 \\
\hline Average & 252 & 13.86 & 56.64 & 75.94 & 148 & 31.39 & 12.14 \\
\hline$L S D_{05 / 01}$ & $\begin{array}{c}4.87 / \\
6.83 \\
\end{array}$ & $\begin{array}{c}0.590 / \\
0.830 \\
\end{array}$ & $\begin{array}{l}1.14 / \\
1.60\end{array}$ & $\begin{array}{l}3.211 \\
4.50\end{array}$ & $\begin{array}{l}4.87 / \\
6.82 \\
\end{array}$ & $\begin{array}{c}0.729 / \\
1.02\end{array}$ & $\begin{array}{c}0.0441 \\
0.062 \\
\end{array}$ \\
\hline
\end{tabular}

Note: CP - crude proteins, CF - crude fat, WSC - water soluble carbohydrates, CFib - crude fibre, NDF neutral detergent fibre, $\mathrm{CA}$ - crude ash, $\mathrm{ME}$ - metabolizable energy.

In general, the values of different grain nutrient parameters were higher at site I. However, these differences were less apparent than those in biomass at pod development stage. Overall, the content of nutritional elements in sole faba bean grain 
was by $2.65-18.38 \%$ higher compared with faba bean - wheat mixture grains in site I and by $20.94-37.26 \%$ higher in site II. Except for CF, Rhizobium application did not increase the content of the studied parameters. It is known that a clear inverse relationship exists between protein and fat content in grains of many crops; that is with decreasing $\mathrm{CP}$ content, the $\mathrm{CF}$ content increases.

Despite the lower nutritional elements content, the higher amount of metabolizable energy was estimated in the grain from site II. As well, higher amount of the energy, averaging $13.21 \mathrm{MJ} \mathrm{kg}^{-1}$ was estimated in sole faba bean grains in site I and $13.16 \mathrm{in}$ site II, There is an inverse relationship between CFib and metabolizable energy. Rhizobia application tended to decrease metabolizable energy amount in grains.

\section{Discussion}

Up to now, the development of legume growing technologies has been lagging behind that of cereal crops (Siddique, 2012). Consequently, an increase in the productivity of legumes has also been falling behind so far. Since legume - cereal mixtures are important components in animal husbandry, we intended to compare a sole faba bean sward with a faba bean - spring wheat mixture. At pod development stage, the DM yield of the biomass of mixture tended to be higher than that of faba bean sole crop. However, the grain yield results are unambiguous. Contrary to our expectations, grain yield of the faba bean - wheat mixture was lower than that of sole faba bean (site II, Véžaičiai). Yet, some authors suggest that depending on the crop mixture, competition for water and nutrients, the yields in some cases might decrease (Yadav and Yadav, 2001; Olowe and Adeyemo, 2009). Our research findings do not always agree with those reported by other authors. Some research evidence suggests that cultivation of two or more crops in a mixture has the potential to achieve higher grain yields than do sole crop systems by improving efficient use of water, light, and nutrients (Zhang et al., 2010; Arlauskienè et al., 2011). However, other authors argue that faba bean - cereal mixtures do not necessarily increase faba bean sward grain yield or biomass productivity (Scalise et al., 2015).

One of the most important factors, which limit crop productivity, is the $\mathrm{N}$ fixation efficiency. It has been documented that inoculated plants activate nitrogen fixation, increase the rate of photosynthesis and respiratory enzymes; therefore, plants produce higher yields (Lapinskas, 2008). Legume bacteria sensitively react to a wide range of environmental conditions, including moisture, aeration, temperature and lighting variations (Köpke and Nemecek, 2010). Among other legumes, faba bean yield highly depends on $\mathrm{N}$ fixation efficiency (Jensen et al., 2010). $\mathrm{N}$ fixation efficiency as well as faba bean yields highly vary (Jensen et al., 2010; Foyer et al., 2016). In dry vegetation periods, the limiting biotic factor in the upper layer of Cambisols is high amount of clay particles, which leads to low aeration and crust formation. Still, clay soils are characterized by a weaker microbial activity and less favourable conditions of soil fauna (Janušauskaite et al., 2008). In turn, Albeluvisols are traditionally acid soils, in which mobile aluminium and its toxic effect on plant roots are important limiting factors for many traditional crops. In both cases, taking into account these yield limiting factors, faba bean productivity might be increased by the application of the following practices: seed inoculation with bacterial products, optimization of the basic soil tillage, crop rotation diversification of basic and catch crops (Verhulst et al., 2010). These 
experiments confirmed the positive effect of Rhizobia bacteria on DM increment as well as grain yield at both experimental sites.

Another issue we addressed in our research was chemical parameters of the biomass. In particular, faba bean plants are valued as protein feed (Voisin et al., 2014), which is required for weight gain of ruminants, milk production, maintenance of vital and reproductive functions (Butkutè, 2011) and are also suitable for monogastric animals (Jezierny et al., 2010) and laying hens (Koivunen et al., 2014). We found that there are few published data on how well the bacterial fertilizer affects different nutritional parameters of legumes. We expected to emphasize the role of Rhizobium to nutrient composition. Although there were significant differences in the parameters between the both study sites, the direct effect of Rhizobia application on nutrient parameters in the biomass as well as in grains was less explicit. Ascertainment of the role of bacterial agents for chemical parameters of the biomass warrants more precise experiments. Moreover, further studies on the current topic are required to validate the positive role of legumes, particularly faba bean in agricultural systems and to more comprehensively elucidate the effects of Rhizobium (or other bacterial strains) on plants and their nutritional quality.

Acknowledgements. The study was conducted in compliance with the long-term program "Plant biopotential and quality for multifunctional practice".

\section{REFERENCES}

[1] Arlauskienė, A., Maikštenienè, S., Šarūnaite, L., Kadžiulienė, Ž., Deveikytè, I., Žèkaitè, V., Česnulevičienè, R. (2011): Competitiveness and productivity of organically grown pea and spring cereal intercrops. - Žemdirbystė=Agriculture 4(98): 339-348.

[2] Bedoussac, L., Journet, E.P., Hauggaard-Nielsen, H., Naudin, C., Corre-Hellou, G., Jensen, E.S., Justes, E. (2015): Ecological principles underlying the increase of productivity achieved by cereal-grain legume intercrops in organic farming. A review. Agronomy for Sustainable Development 35(3): 911-935.

[3] Bloemberg, G.V., Lugtenberg, B.J.J. (2001): Molecular basis of plant growth promotion and biocontrol by rhizobacteria. - Current opinion in plant biology 4: 343-350.

[4] Butkute, B. (2011): Quality of silages of different origin and variation of fibre components. - Veterinarija ir zootechnika 51(73): 8-16 (in Lithuanian, English abstr.).

[5] Deaker, R., Roughley, R.J., Kennedy, I.R. (2004): Legume seed inoculation technologya review. - Soil Biology and Biochemistry 36(8): 1275-1288.

[6] Elkoca, E., Kantar, E., Sahin, F. (2007): Influence of nitrogen fixing and phosphorus solubilizing bacteria on the nodulation, plant growth, and yield of chickpea. Journal of Plant Nutrition 31 (1): 157-171.

[7] Foyer, Ch.H., Lam, H-M., Nguyen, H.T., Siddique, K.H.M., Varshney, R.K., Colmer, T.D., Cowling, W., Bramley, H., Moris, T.A., Hodgson, J.M., Cooper, J.W., Miller, A.J., Kunert, K., Vorster, J., Cullis, Ch., Ozga, J.A., Wahlqvist, M.L., Liang, Y., Shou, H., Shi, H., Yu, J., Fodor, N., Kaiser, B.N., Wong, F-L., Valliyodan, B., Considine, M.J. (2016): Neglecting legumes has compromised human health and sustainable food production. Nature plants 2: 1-10.

[8] Herridge, D.F., Peoples, M.B., Boddey, R.M. (2008): Global inputs of biological nitrogen fixation in agricultural systems. - Plant and Soil 311(1-2): 1-18. 
[9] Janušauskaite, D., Velykis, A., Satkus, A. (2008): The influence of agricultural practices intended for the improvement of clay loam topsoil and subsoil on the microbiological processes. - Žemdirbystė=Agriculture 95 (2): 45-60 (in Lithuanian, English abstr.).

[10] Jensen, E.S., Peoples, M.B., Hauggaard-Nielsen, H. (2010): Faba bean in cropping systems. - Field crops research 115(3): 203-216.

[11] Jensen, E.S., Bedoussac, L., Carlsson, G., Journet, E-P., Justes, E., Hauggaard-Nielsen, H. (2015): Enchancing yields in organic crop production by eco-functional intensification. - Sustainable Agriculture research 4 (3): 42-49.

[12] Jezierny, D., Mosenthin, R., Bauer, E. (2010): The use of grain legumes as a protein source in pig nutrition: A review. - Animal Feed Science and Technology 157: 111-128.

[13] Köpke, U., Nemecek, T. (2010): Ecological services of faba bean. - Field Crops Research 115: 217-233.

[14] Koivunen, E., Tuunainen, P., Valkonen, E., Rossow, L., Valaja, J. (2014): Use of faba beans (Vicia faba L.) in diets of laying hens. - Agricultural and food science 23: 165-172.

[15] Lapinskas E (2006) The effect of legume inoculation with rhizobium strains and starter nitrogen on symbiotic nitrogen fixation and soil agrochemical properties. Agriculture 93(2), p. 3-24.

[16] Lapinskas, E. (2008): Nitrogen changes in soils and importance for the plants. (ArxBaltica: Kaunas): 319.

[17] Magrini, M.B., Anton, M., Cholez, C., Corre-Hellou, G., Duc, G., Jeuffroy, M.H., Walrand, S. (2016): Why are grain-legumes rarely present in cropping systems despite their environmental and nutritional benefits? Analyzing lock-in in the French agrifood system. - Ecological Economics 126: 152-162.

[18] McKenzie, D.B., Spaner, D. (1999): White lupin: An alternative to pea in oat-legume forage mixtures grown in Newfoundland. - Canadian Journal of Plant Science 79: 43-47.

[19] Nemecek, T., von Richthofen, J.S., Dubois, G., Casta, P., Charles, R., Pahl, H. (2008): Environmental impacts of introducing grain legumes into European crop rotations. European journal of agronomy 28(3): 380-393.

[20] Olowe, V.I.O., Adeyemo, A.Y. (2009): Enhanced crop productivity and compatibility through intercropping of sesame and sunflower varieties. - Annals of Applied Biology, 155(2): 285-291.

[21] Pascual, U., Perrings, C. (2007): Developing incentives and economic mechanisms for in situ biodiversity conservation in agricultural landscapes. -Agriculture, Ecosystems \& Environment 121: 256-268.

[22] Pilorgé, E., Muel, F. (2016): What vegetable oils and proteins for 2030? Would the protein fraction be the future of oil and protein crops? OCL 23(4): 2-10.

[23] Scalise, A., Tortorella, D., Pristeri, A., Petrovičová, B., Gelsomino, A., Lindström, K., Monti, M. (2015): Legume-barley intercropping stimulates soil N supply and crop yield in the succeeding durum wheat in a rotation under rainfed conditions. - Soil Biology and Biochemistry 89: 150-161.

[24] Siddique, K.H., Johansen, C., Turner, N.C., Jeuffroy, M.H., Hashem, A., Sakar, D., Alghamdi, S.S. (2012): Innovations in agronomy for food legumes. A review. Agronomy for sustainable development 32(1): 45-64.

[25] Strydhorst, S.M., King, J.R., Lopetinsky, K.J., Harker, K.N. (2008): Forage potential of intercropping barley with faba bean, lupin, or field pea. - Agronomy Journal 100(1): 182190.

[26] Šarūnaitė, L., Deveikytè, I., Arlauskienè, A., Kadžiulienė, Ž., Maikštėnienė, S. (2013): Pea and spring cereal intercropping systems: advantages and suppression of broad-leaved weeds. - Polish Journal of environmental studies 22(2): 541-551.

[27] Tarakanovas, P., Raudonius, S. (2003): Statistic analysis of agronomical research data with computer programs ANOVA, STAT, SPLIT-PLOT from packet SELEKCIJA and IRRISTAT. (Aleksandras Stulginskis University: Akademija (Kaunas district)): 56. (in Lithuanian). 
[28] Verhulst, N., Govaerts, B., Verachtert, E., Castellanos-Navarrete, A., Mezzalama, M., Wall, P., Sayre, K.D. (2010): Conservation agriculture, improving soil quality for sustainable production systems. - In: 'Advances in soil science: food security and soil quality' (CRC Press: Boca Raton): 137-208.

[29] Voisin, A.S., Guéguen, J., Huyghe, C., Jeuffroy, M.H., Magrini, M.B., Meynard, J.M., Pelzer, E. (2014): Legumes for feed, food, biomaterials and bioenergy in Europe: a review. - Agronomy for Sustainable Development 34(2): 361-380.

[30] Yadav, R.S., Yadav, O.P. (2001): The performance of cultivars of pearl millet and clusterbean under sole cropping and intercropping systems in arid zone conditions in India. - Experimental Agriculture 37(02): 231-240.

[31] Zhang, N.N., Sun, Y.M., Li, L., Wang, E.T., Chen, W.X., Yuan, H.L. (2010): Effects of intercropping and Rhizobium inoculation on yield and rhizosphere bacterial community of faba bean (Vicia faba L.) - Biology and fertility of soils 46(6): 625-639. 